\title{
Analysis on the Development Strategies of Public Libraries in Western Regions in the Age of Nationwide Reading
}

\author{
Yuan Chen \\ Library \\ Liupanshui Normal University \\ Liupanshui, China 553001
}

\begin{abstract}
The economic foundation of poverty areas in the west is backward, and the development of education and information technology lags behind. In the construction of ecological civilization and the building of the socialist harmonious society in China, the development of public libraries has been highly valued by the party and the government. The western region has a vast territory, a large number of ethnic groups, and a long history. It is rich in local literature resources in economics, politics, culture, ethnicity, science and technology, and history. These resources provide important literature information for developing the western region's economy and broadening the path to riches.
\end{abstract}

\section{Keywords—western region; China dream; public library}

\section{INTRODUCTION}

In order to build a western region where people's life is stable, with economic prosperity, social progress, national unity, beautiful natural environment and rich people, and in order to specifically deploy the strategy for the development of the western region, the Fourth Session of the Ninth National People's Congress passed Outline of the Tenth Five-Year Plan for National Economic and Social Development of the People's Republic of China in March 2001. Relying on the southwest sea passage, the Eurasian Land Bridge, and the Yangtze River waterway trunk line, fully playing the role of the central cities to drive the development of other areas, from the points to the surfaces, and from the points to the lines, form Chinese distinctive economic belts across administrative regions such as Yangtze River upstream economic belt, west of LanzhouLianyungang Railway and Lanzhou-Xinjiang Railway economic belt, and Chengdu-Kunming economic belt. On December 8, 2006, executive meetings of the State Council reviewed and approved the 11th Five-Year Plan for the Development of the Western Region, requiring to realize new breakthroughs in infrastructure and ecological environment construction in the western region, the development of key regions and key industries to meet new standards, the equalization of basic public services such as education and health to achieve new results, the economy to develop rapidly and well, and the people's living standards to be improved continuously and steadily.

\section{THE DEVELOPMENT OF THE WESTERN REGION AND THE CONSTRUCTION OF THE PUBLIC LIBRARY SERVICE SYSTEM}

Since the implementation of the strategy of developing the western region, the country's poverty-stricken areas in the west are undergoing great changes. This is not only reflected in the rapid development of the economy and the improvement of people's material living standards. The library career has also developed with the development of the economy and the improvement of living standards. The economic development of the western region is a project of powering the country and enriching the people. Accordingly, the prosperity of the public libraries cannot be achieved overnight. The Outline of the National Cultural Reform Plan during the 13th Five-Year Plan clearly states: "We should correctly balance the development of the eastern region and the central and western regions, and balance the development of urban and rural areas, and strengthen the support for the construction of the public cultural service system in the central and western regions and the vast rural areas, and promote the equalization of public cultural services." In China, to achieve the core values of socialism, the government must innovate ideas and do a good job in the development of public libraries.

The universal equalization and full coverage of services of public libraries is the main approach to guarantee that people can enjoy social and cultural resources fairly and information fairness can be achieved. Establishing a public library service system with reasonable layout, complete facilities, complete functions and convenient services in an area can meet the spiritual and cultural needs of people at all levels of society. The Chinese government has actively implemented the "Internet + " action plan and introduced a series of public policies on "Internet +", such as the Internet of Things, cloud computing, China Manufacturing 2025, and Big Data, to support various Internet-based innovations. (Huangmei 2008, 5) According to Internet World Stars statistics, the number of Internet users in the world is growing rapidly. In 2007, the top ten countries in the world for the amount of netizens were: the United States, with 210, 575, 287 netizens, the penetration rate was $71.9 \%$; China, with $163,000,000$ netizens, the penetration rate was $12.3 \%$; Japan, with $86,300,000$ netizens, the penetration rate was $67.1 \%$. There were $1,244,449,601$ 
netizens in the world, and the penetration rate was $18.9 \%$. Netizens search information through the network, effectively acquire various knowledge, and are already unable to leave the network.

\section{A. Cultural Development Gap Between the Eastern and Western Regions}

The economic foundation of the poverty-stricken areas in the west is backward, and the development of education and information technology is lagging behind, but many original ecological natural landscapes and humanistic ecological resources such as folk customs and revolutionary memorial sites have been preserved. These resources have been highly valued by the party and the people in the national development strategy of the western region and the ecological civilization construction of building a socialist harmonious society, and have become an important part of the development goals of beautiful China. From the development of the western region to the construction of a socialist harmonious society to today's "The Belt and Road" development strategy, the economic, social and cultural development of the poverty-stricken areas in the west has been strongly supported by national policies. Accelerating the construction of the public cultural service system in poverty-stricken areas is an important task for serving the overall situation of getting rid of poverty and building a modern public cultural service system.

\section{B. Guaranteeing the Basic Cultural Rights and Interests of Citizens Is the Sacred Duty of Public Libraries}

Establishing a public cultural service system with reasonable structure, balanced development, sound network, and effective operation which can benefit the whole people is one of the important goals of the party and the state to build a well-off society in an all-round way. It is also important guarantee to safeguard the basic cultural rights and interests of citizens and meet the basic cultural needs of people and the inevitable requirement for maintaining fair and just public cultural life and promoting social harmony and stability. The government needs to change its functions, actively and effectively control the differences between libraries in different regions, ensure the balanced investment for all kinds of libraries, properly solve the digital gap problems between libraries, and strive to build a comprehensive and reasonable supervision mechanism to ensure nationwide libraries to coordinate and cooperate with each other and provide a strong guarantee for building public cultural equal service for the whole society. The development of public libraries reflects the progress of society and carries the ideal of public life and people's cultural appeals. Public libraries have the responsibility to guarantee the basic cultural rights of citizens.

Reading is the basic cultural needs and cultural rights of people. When the country's Real GDP per capital reaches 3,000 US dollars, cultural consumption will grow rapidly. In 2014, China's Real GDP per capital has reached about 7,800 US dollars, and the cultural needs and consumption of the people have entered a period of prosperity. The report of the 18th National Congress of the Communist Party of China incorporated the "carrying out nationwide reading activities" into the construction of cultural powerful socialist country of
China. Two sessions (NPC and CPPCC) have written the "promoting nationwide reading and building a scholarly society" into the "Report on the Work of the Government". Various parts of the country have responded to the nation's call and carried out a variety of reading activities.(Building an innovative country learning book writing group 2006, 2 (123128)) People's knowledge level will be higher and higher, lifelong learning will become an inevitable requirement, and the whole society will become a learning society.

\section{StRENGTHENING CUltural SERVICES IN THE CENTRAL AND WESTERN REGIONS, AND REALIZING THE SUSTAINABLE DEVELOPMENT OF PUBLIC LIBRARIES IN THE WESTERN REGION}

Currently, the state requires all regions to carry out major information engineering constructions such as "Broadband Chinese" and "Smart Cities" in accordance with their own conditions, coordinate the implementation of national cultural information resources sharing, and accelerate the digital construction of cultural service institutions. Accelerate the construction of digital libraries and museums, conduct digital cinema screenings in rural areas, provide public services of direct broadcast satellite radio and television, accelerate the construction of urban and rural electronic reading screens, and build digital rural libraries. Establish interconnected public digital cultural service network with unified standards to achieve resource sharing.

\section{A. An Important Period of Strategic Opportunities for the Construction of the Public Library Service System in the Western Region of China Is Coming}

Mao Zedong pointed out in the opening speech of the first plenary session of the Chinese People's Political Consultative Conference that: With the advent of the economic construction climax, there will inevitably be a climax of cultural construction. Engels also said: "Culture is rooted in a certain stage of economic development of a nation in an era." Carnegie believes: "The best way to benefit the society is to provide the people with a ladder to make progresses - to build parks and recreational facilities in order to benefit people's physical and mental health; to arrange artistic activities to delight people's spirit and improve people's aesthetic ability; to develop various public facilities to improve the living environment of human beings.

Compared with the readers in university libraries and institutional libraries, the readers in public libraries come from more diverse social classes and have a variety of knowledge needs. The construction of a public cultural service system covering the whole society has become a national strategy. The public library service system, as an important part of the public cultural service system, is a priority development target. As China's comprehensive national power is being stronger, the economic foundation for the development of public cultural career has been continuously consolidated and strengthened, and the basic conditions for the construction of public library service system are already in place. The regional public library service networks have been built successively. The "Shanghai model", "Guangzhou model", "Shenzhen model" and "Jiaxing 
model" have emerged one after another, and their role of demonstration and leading has gradually appeared.

\section{B. Public Library Is A Place for People to Learn Knowledge, Information, Ideology and Culture.}

Public libraries are the main front for the construction of reading culture. The development of public libraries is determined by the socialist nature of China and is the need for China to govern the country according to laws. And public libraries are the necessary institutions for realizing the great rejuvenation of the Chinese nation. There are two main forms of building public libraries, state-run and civilian-run. Staterun refers to that the library is invested and established by the people's governments at various levels, and civilian-run refers to that the library is invested and established using the donation of the society. The library is a place for people to learn knowledge, ideas and culture. With the help of the realization of the China dream, using libraries' advanced communication technologies and rich collection resources, make libraries play a positive role in promoting the socialist core value system and interpreting the connotation of China's excellent culture. Article 22 of the 1982 Constitution states: "The country develops the literary and artistic undertakings, the news, broadcasting and television undertakings, the publishing business, the libraries, museums, cultural centers and other cultural undertakings which serve the people and the socialism, and carries out mass cultural activities." This reflects the development of the library business is the essential requirement of the socialist countries.

The investment of financial funds plays an irreplaceable role in the development of the library business. The financial investment of the relevant government departments in China for the libraries under their jurisdiction has laid the foundation for the sustainable development of the libraries. The strategy of the development of the western region in China is a major decision made by the Party Central Committee from the actual situation and will play a very important role in the development of the entire western region. There are hundreds of district-level public libraries in the 12 provinces in the west, and there are thousands of literature and information institutions. They provide local governments and scientific research institutions with services of collecting and sorting out economic, political and cultural information and scientific research services. However, many prefecture-level and countylevel libraries in the western region are unable to effectively perform their social functions due to restrictions on their working environments and funding, and their service scopes are narrowed. In the era of promoting nationwide reading and building a scholarly society, how to seize the opportunity and take effective measures to develop the western public culture is a topic that public libraries in the western region must consider.

\section{CONCLUSION}

(Wang Yingqi 2011, 9) As we all know, China's public library services are still not perfect in terms of "equal opportunities". The right to access public library services between urban residents and rural residents is not equal, and the right to obtain public library services between residents in developed eastern regions and residents in less developed central and western regions is not equal. The significance of building a "universal equal" public library service system in China lies in solving the problem of "unequal opportunities and rights". Throughout the development history of libraries at home and abroad, the world's first public library can be traced back to the ancient Roman period of BC. The first public library in China was the Guyue Library, which was built in 1902. In the long course of development, there has formed a relatively complete set of library management theories, management processes, management methods and business systems, business structures and business models. The rich economic, cultural, political, scientific, national, and historical literature resources of the western region are preserved in local libraries in the forms of local chronicles, archives, rare books, ancient books, and scriptures, providing favorable design bases and original materials for the economic construction of the western region, and providing important literature information services for the development of the western region's economy and the broadening of people's access to wealth.

\section{REFERENCES}

[1] Huang Mei. 2008 Librarians' views on Google. [J] Digital Library Forum. (5): 53.

[2] Building an innovative country learning reader writing group. 2006 Building an innovative country learning reader $[\mathrm{M}]$ Beijing, Xinhua Press. (2) pp.123-128.

[3] Wang Yingqi. 2011 Universal Equalized Public Library Service System: Concepts, Obstacles and Countermeasures [J] Library Theory and Practice (9): 69 